\title{
Influenza among adults in Latin America, current status, and future directions: a consensus statement
}

\author{
Pablo E. Bonvehí, ${ }^{1}$ Raúl E. Istúriz, ${ }^{2}$ Jaime A. Labarca, ${ }^{3}$ \\ Ricardo W. Rüttimann, ${ }^{4}$ Edison I. Vidal, ${ }^{5}$ and Diana Vilar-Compte ${ }^{6}$
}

Suggested citation Bonvehí PE, Istúriz RE, Labarca JA, Rüttimann RW, Vidal EI, Vilar-Compte D. Influenza among adults in Latin America, current status, and future directions: a consensus statement. Rev Panam Salud Publica. 2012;31(6):506-12.

\begin{abstract}
In Latin America, adult influenza is a serious disease that exacts a heavy burden in terms of morbidity, mortality, and cost. Although much has been written about the disease itself, relatively little information has been compiled on what could be done to reduce its impact across the region, particularly from the perspective of clinicians with firsthand experience in confronting its effects. To fill this data gap, in 2011, the Pan American Health and Education Foundation (PAHEF) and the U.S.-based nonprofit Fighting Infectious Diseases in Emerging Countries (FIDEC) organized a conference and convened a panel of Latin American scientistclinicians with experience and expertise in adult influenza in the region to 1) discuss the major issues related to the disease and 2) develop and produce a consensus statement summarizing its impact as well as current efforts to diagnose, prevent, and treat it. The consensus panel concluded a more concerted and better-coordinated effort was needed to reduce the adverse impact of seasonal influenza and future pandemics, including more surveillance, more active involvement by both governmental and nongovernmental organizations, and a much greater effort to vaccinate more adults, especially those at high risk of contracting the disease. In addition, a new approach for diagnosing influenza was recommended.
\end{abstract}

Key words Influenza, human; immunization; influenza vaccines; adult; consensus development conferences as topic; Latin America.

Influenza is a highly infectious, acute disease caused by A, B, and C influenza viruses. The World Health Organization (WHO) estimates the global disease burden from influenza to be of up to 1 billion individuals infected, 3-5 million cases

Centro de Educación Médica e Investigaciones Clínicas "Norberto Quirno" (CEMIC), Buenos Aires, Argentina.

Centro Médico de Caracas, Caracas, Venezuela.

3 Pontificia Universidad Católica de Chile, Santiago, Chile.

4 Fighting Infectious Diseases in Emerging Countries (FIDEC), Miami, Florida, United States of America. Send correspondence to: Ricardo W. Rüttimann, rruttimann@fidec-online.org

5 Universidade Estadual Paulista, São Paulo, Brazil.

6 Instituto Nacional de Cancerología, Mexico City, Mexico. of severe disease, and 300 000-500000 deaths annually (1). In the United States, annual epidemics have been associated with an estimated 36000 deaths and 226000 hospitalizations (2). In Latin America, lower respiratory tract infections are the third most frequent cause of death in individuals aged 65 years or older $(3,4)$. Over the last decade, the majority of high-income countries and several low- and middle-income countries recommended vaccination for the following three groups: 1) individuals $>65$ years old, 2) nursing home and long-term care facility residents, and 3 ) patients with chronic comorbidities (5). In a 2005 position paper, WHO recom- mended a goal of $75 \%$ vaccination coverage among those $>65$ years by 2010 (5). In 2008, prior to the 2009 influenza A(H1N1) pandemic, approximately 166 million doses of seasonal influenza vaccines were distributed throughout Latin America, but targeted risk group coverage was low and widely variable (6) Adult influenza is a serious threat to public health in the region that exacts a heavy burden in terms of morbidity, mortality, and cost. Although much has been written about the disease itself, relatively little information has been compiled on what could be done to reduce its impact across Latin American countries, particularly from the perspective 
of clinicians with firsthand experience in confronting its effects.

To fill this data gap, the Pan American Health and Education Foundation (PAHEF) and the U.S.-based nonprofit Fighting Infectious Diseases in Emerging Countries (FIDEC) organized a conference and convened a consensus panel of Latin American scientist-clinicians with experience and expertise in adult influenza in the region to 1) discuss the major issues related to the disease and 2) develop and produce a consensus statement summarizing its impact as well as current efforts to diagnose, prevent, and treat it.

\section{CONSENSUS PANEL AND CONFERENCE}

The goal of the influenza consensus panel and conference (Influenza Among Adults in Latin America: Current Status and Future Directions), held in Miami, Florida, from April 25 to 28, 2011, was to address five key questions about adult influenza in Latin America and to produce a consensus statement on the current status and potential future directions of the disease across the region. The consensus panel (the Panel) included six Latin American physicians with expertise in adult influenza who are members of various Latin American scientific societies and experts in influenza vaccines (PEB, REI, RWR); strategies for prevention (EIV, REI); epidemiology (DVC, RWR); and diagnosis and treatment (JAL, DVC, PEB). Conference organizers also conducted a thorough literature review to identify articles that 1) were published from 2000-2011; 2) covered clinical aspects of adult-onset influenza in Latin America and/or national and international guidelines for prevention and control of the disease; 3 ) were based on clinical trials or observational studies; and 4) clearly identified the study design and population. Abstracts and synopses of meetings were not included. Over 200 papers met these criteria and were provided to the Panel prior to the conference, along with the following five key questions:

1. What is the current epidemiology of influenza in Latin America?

2. What is the status of surveillance and diagnosis?

3. What are the recommendations for adult immunization and how successful have they been?
4. What governmental and nongovernmental organization (NGO) policies are needed to reduce the burden of influenza in Latin America?

5. What medical interventions are needed to reduce the adverse impact of influenza in Latin America?

During the conference, the Panel discussed the scientific evidence from the literature review as it related to the five questions, and drafted a response to each one. The responses then underwent a review-revision process, based on group discussions, until unanimous consensus was reached. After the conference, the Panel continued to review and fine-tune the responses. The final consensus responses to the five key questions about influenza are presented below.

\section{CONSENSUS RESPONSES}

\section{What is the current epidemiology of influenza in Latin America?}

Influenza is a systemic viral infection of worldwide importance that mainly affects the upper and lower respiratory tract, spreads rapidly, and is easily transmitted from person to person via droplets and small particles $(7,8)$. The incubation period is approximately 1 to 4 days and can be as long as 7 days. In most cases, infected individuals who were previously healthy can transmit the disease from about 24 hours before symptoms appear to about 5 to 10 days after that. Different viral strains may display different transmission dynamics (9). Most infected people recover within 1 to 2 weeks without medical treatment. Groups at higher risk for developing influenza-related complications include children (especially those younger than 2 years); adults $\geq 65$ years; individuals who have chronic medical conditions or who are immunocompromised; pregnant women; and the obese (10).

The epidemiology of influenza in Latin America varies considerably, primarily due to seasonal differences between countries, and variations in climate and vaccine coverage $(11,12)$. For example, Southern Hemisphere wild circulating strains may differ from Northern Hemisphere wild strains, even within a given year. Differences have also been observed in epidemiological patterns for countries in temperate climates versus those in tropical and subtropical climates $(13,14)$, and in surveillance and health care delivery systems across the region (15).

Determining the epidemiology and severity of influenza in the different countries of Latin America is crucial for fighting the disease region-wide. Therefore, the Panel urges all health authorities, NGOs, and medical societies in the region to make a concerted effort to enhance their surveillance systems and reporting capabilities. Ideally, data collection should be consistent across countries to make region-wide epidemiological determinations more reliable.

\section{What is the status of surveillance and diagnosis?}

The antigenic profiles of influenza viruses change constantly. Major antigenic changes can cause pandemics because of the high proportion of the population that is susceptible to the viruses. Active monitoring of disease activity is critical for determining viral biological changes and monitoring disease activity in comparison to other respiratory viruses. Surveillance is also necessary to monitor the occurrence of outbreaks. WHO recommends that surveillance be conducted and adapted locally for seasonal, pre-pandemic, and pandemic phases. Several surveillance networks have been created to update and share data (e.g., FluNet, 7 a WHO-sponsored influenza outbreak monitoring site). National references laboratories provide more specific information, such as the strain of influenza virus (e.g., $\mathrm{A}(\mathrm{H} 1 \mathrm{~N} 1)$, $\mathrm{A}(\mathrm{H} 3 \mathrm{~N} 2)$, or B) and its susceptibility to antivirals. Surveillance data also provide valuable information to $\mathrm{WHO}$ Collaborating Centers ${ }^{8}$ for the antigenic and genetic analyses that are required to develop future vaccine formulation recommendations (16). This type of surveillance information should be collected, analyzed, and reported regularly so that the information is available throughout the year.

There are several methods for specific virologic surveillance and clinical diagnosis (17). The one most widely available is the direct immunofluorescent assay. The disadvantages of this method are its low sensitivity to new viruses with major antigenic changes, including $\mathrm{A}(\mathrm{H} 1 \mathrm{~N} 1)$, and the fact that it does not provide information about influenza A subtypes.

\footnotetext{
7 www.who.int/flunet/

8 www.who.int/collaboratingcentres/en/
} 
Viral culture techniques are valuable for typing and subtyping of influenza A and B. However, they 1) lack sensitivity to new virus strains, because they require antigenic reagents, and 2) may require up to 10 days to produce results, making them less useful for rapid surveillance. Serological analyses measure influenza-specific antibodies and are thus a good choice for determining the prevalence and dynamics of infection and vaccine response.

During the 2009 A(H1N1) pandemic, previously developed molecular tools such as reverse transcriptase PCR (RTPCR) were made available for the diagnosis and surveillance of the new virus. Another assay that became widely available after the 2009 outbreak is realtime PCR (rRT-PCR), which is now a preferred method for surveillance and diagnosis.

Drug-resistant therapy. Antiviral drugs are the best option for treatment and are also used for prevention. However, all currently circulating influenza viruses are resistant to at least one of the two major classes of these drugs (adamantanes and neuraminidase inhibitors) (18). Drug resistance can be assessed by phenotypic and genotypic methods. The latter method has been used to detect a mutation in the active site of neuraminidase $\mathrm{H} 275 \mathrm{Y}$ that is associated with oseltamivir resistance (but not zanamivir resistance). Genotypic methods are also used to detect V27A and S31N mutations in the influenza A virus associated with $97 \%$ of amantadine resistance.

A(H1N1) pandemic. Prior to the 2009 pandemic, most surveillance was performed through regional reference centers. Few Latin American countries performed regular surveillance, although at least 15 of them had a pandemic preparedness plan in place (19). After the pandemic, most Latin American countries strengthened their influenza surveillance system.

Pathogen identification. The diagnosis of influenza based on typical clinical symptoms is more accurate when the virus is circulating in the community. Because influenza symptoms are non-specific and indistinguishable from those of other respiratory viruses, determining the exact respiratory pathogen circulating within a given community is important.

While laboratory confirmation of the diagnosis is seldom critical in otherwise healthy adults during seasonal influenza, it is important in certain population groups. For example, laboratory confirmation is recommended if the patient is older, immunosuppressed, or respiratory-compromised; has severe chronic co-morbidities; or needs to be admitted to the hospital. Also, patients experiencing severe influenzalike symptoms outside of an epidemic period should be given a diagnostic test. Laboratory confirmation is also recommended in facilities and environments where individuals are in close physical contact.

Rapid tests for influenza take 10-15 minutes and are easy to perform. However, they lack sensitivity and can not differentiate influenza A virus subtypes, and are thus most useful for screening. Assays using fluorescent antibodies are widely available for the detection of influenza and other respiratory viruses, and take 4-6 hours to produce results (20). However, their relatively low sensitivity for detecting $\mathrm{A}(\mathrm{H} 1 \mathrm{~N} 1)$ limits their usefulness, despite their relatively great sensitivity for detecting other influenza

TABLE 1. Sensitivity and specificity of various methods for diagnosing influenza, based on literature review ${ }^{a}$ for consensus conference ${ }^{b}$ on adult influenza in Latin America, Miami, Florida, 2011

\begin{tabular}{|c|c|c|}
\hline Method & Time to results & Sensitivity and specificity \\
\hline Rapid influenza diagnostic tests & 10-20 minutes & $\begin{array}{l}\text { Low-to-moderate sensitivity and high } \\
\text { specificity. Limitations of the test should be } \\
\text { recognized when interpreting results. }\end{array}$ \\
\hline Direct immunofluorescence & $2-4$ hours & $\begin{array}{l}\text { Moderately high sensitivity and high } \\
\text { specificity; recommended. Does not } \\
\text { confirm influenza } A(\mathrm{H} 1 \mathrm{~N} 1) \text {. Detects and } \\
\text { distinguishes between influenza } A \text { and } B \\
\text { and between } A / B \text { and other respiratory } \\
\text { viruses. }\end{array}$ \\
\hline $\begin{array}{l}\text { RT-PCR (conventional PCR, real-time } \\
\text { PCR) }\end{array}$ & 2 hours & $\begin{array}{l}\text { High sensitivity and very high specificity; } \\
\text { recommended. Best method for influenza } \\
\text { A(H1N1). }\end{array}$ \\
\hline $\begin{array}{l}\text { Viral culture } \\
\text { Shell vial culture } \\
\text { Isolation in cell culture }\end{array}$ & $\begin{array}{l}48-72 \text { hours } \\
3-10 \text { days }\end{array}$ & $\begin{array}{l}\text { Moderately high sensitivity and highest } \\
\text { specificity. This test is important for public } \\
\text { health surveillance but is not useful for } \\
\text { timely clinical management. }\end{array}$ \\
\hline Serologic tests & Not applicable & $\begin{array}{l}\text { Available in reference laboratories; not } \\
\text { useful for timely clinical management; } \\
\text { recommended for retrospective diagnosis, } \\
\text { surveillance, and research purposes. }\end{array}$ \\
\hline
\end{tabular}

\footnotetext{
a Adapted from Harper et al. (20).

b Influenza Among Adults in Latin America: Current Status and Future Directions (25-28 April), organized by Pan American Health and Education Foundation (PAHEF) and the U.S.-based nonprofit Fighting Infectious Diseases in Emerging Countries (FIDEC).

c Multiplex PCR can detect influenza, including $\mathrm{A}(\mathrm{H} 1 \mathrm{N1})$, and other respiratory conditions.
}

viruses. RT-PCR and rRT-PCR are the preferred methods for both diagnosing the $\mathrm{A}(\mathrm{H} 1 \mathrm{~N} 1)$ virus and complementing other means of diagnosis of influenza A diagnosis and only provide retrospective nformation.

Based on the scientific evidence and the Panel recommends the following test sequence for diagnosing influenza: First, a sample should be sent for direct immunofluorescence testing. If the result is negative, either an RT-PCR or rRT-PCR should be performed to confirm the absence of influenza virus. In facilities out access to any PCR methodolmany other influenza cases in the population should be considered suggestive of influenza. If neither fluorescent antibody nor PCR methods are available, a definitive diagnosis of influenza cannot be confirmed. Although the Panel recogthe sequence of tests used may the tests and sequence recommend here can serve as a foundation for a less costly approach to diagnosing influenza. Table 1 provides a summary of the sen. Serologic tests have limited utility 
sitivity and specificity of the various methods for diagnosing influenza.

\section{What are the recommendations for adult influenza immunization and how successful have they been?}

Vaccination is the most important measure to reduce the morbidity and mortality associated with influenza. Because strains change almost every year due to changes in surface antigen composition, vaccine formulation should be updated annually.

Post-vaccination serum antibody response, which correlates with the level of protection from infection, reaches a peak at 2-4 months and falls soon thereafter (returning to baseline levels, usually before the next influenza season), so annual vaccination is recommended (22-24).

Before 1999, worldwide vaccines were limited to Northern Hemisphere strains. Improved surveillance since then has resulted in the implementation of WHO recommendations that both Northern and Southern Hemisphere strains be included in the vaccines, which has improved the match between the vaccines and the circulating wild strains (16). For some countries in tropical areas of Latin America, the decision of whether to use a Northern or Southern Hemisphere vaccine remains unclear (25).

Most currently utilized influenza vaccines are inactivated trivalent split or sub-unit (purified surface antigen) preparations and contain two A strains (H1N1 and H3N2) and one B strain (whichever one is forecast as most likely to cause disease in the subsequent season). New and emerging technologies for vaccine preparation (such as cell culture) may be a tremendous advantage in pandemic situations because the production cycle may be shorter than in previous methods (26). Adjuvanted vaccines (both monovalent and trivalent preparations), which produce a more robust immune response, have been studied and are now being used in Latin America (27-29).

The use of intradermally administered vaccines, which are safe and more immunogenic than other types of parenterally delivered non-adjuvanted preparations, is another option that can help improve the immunological response following vaccination $(30,31)$.

Older adults. Although older adults, patients with chronic diseases, and im- munosuppressed transplant individuals exhibit a lesser antibody response than other groups, influenza vaccination in those three populations has been shown to decrease 1) hospitalization and death due to myocardial infarction (32) and 2) hospitalizations due to pneumonia (33). Data from Argentina indicate influenza vaccination reduced pneumonia-related hospitalization by $45 \%$ among elderly people with other co-morbid conditions (33). In Mexico, vaccination was found to be cost-effective in adults aged 65 years and older (4). Adjuvanted trivalent vaccines appear to be effective among older adults, reducing their risk of hospitalization for both influenza and pneumonia $23 \%$ more than non-adjuvanted vaccines (34).

Influenza parenteral vaccines are recommended for women who are pregnant. The antibody response is adequate, and passive antibody transmission to the fetus affords protection for approximately six months after birth (35, 36). Childhood immunization has been shown to contribute to protection against influenza in adults by decreasing the number of susceptible hosts, a phenomenon known as "herd immunity" (37-40). Inactivated influenza vaccines are considered safe, with systemic side effects seen in less than $3 \%$ of the vaccinated population. Contraindications are few and include current fever, severe allergy to egg proteins, and history of GuillainBarré syndrome (41).

For various reasons, including limited economic resources and the paucity of research data on the impact of influenza in various adult subpopulations, recommended coverage in most Latin American countries that advocate influenza immunization for adults only includes those more than 60 or 65 years old. Recently, in some countries in the region, recommended coverage for adult influenza immunization has been expanded to include other emerging highrisk groups.

There is a limited amount of data on vaccination coverage among adults targeted for immunization in Latin America. However, some general findings have been identified. First, immunization programs funded and promoted by the government appear to improve vaccine uptake in adults (42). Second, the proportion of the population that gets vaccinated for influenza is highly vari- able across countries, a situation that is less than desirable if the goal is uniform vaccination of all individuals at high risk region-wide. Third, strategies that include financial incentives and public awareness campaigns improve vaccination coverage (43).

Recently updated recommendations from the U.S. Centers for Disease Control and Prevention (CDC) Advisory Committee on Immunization Practices (ACIP) for influenza vaccine administration advocate immunization for all adults (2). In the long term, these recommendations may also be useful in Latin America, where universal adult immunization is both highly desirable and the ultimate goal. However, at present, the Panel recommends that Latin American countries focus on vaccinating individuals at high risk of acquiring or disseminating the virus and those particularly vulnerable to influenza complications.

\section{What governmental and NGO poli- cies are needed to reduce the burden of influenza in Latin America?}

WHO has developed a framework and checklist to help countries worldwide develop pandemic influenza preparedness (PIP) plans (39). The framework comprises five basic components, all of which are relevant to Latin America: planning and coordination; situation monitoring and assessment; reducing the spread of disease; continuity of health care provision; and communication (44). Recent Pan American Health Organization (PAHO) activities related to the development of a regional, transnational PIP plan include facilitation of planning workshops and self-assessment exercises in various countries in the region, guided by the WHO PIP framework.

Mathematical simulation modeling has been used in various studies to evaluate different ways of addressing influenza pandemics. The results provide important guidance on the public health measures that should be taken for optimal pandemic preparedness (45). For example, the studies have shown that network interventions (e.g., school closures and other types of social distancing methods) and case-based interventions (e.g., quarantine of cases, antiviral treatment, and prophylaxis) have the greatest potential to contain an epidemic and its associated burdens-and that the earlier that these types of control measures 
are implemented, the greater the effect. However, many questions about preparedeness cannot be answered by simulation modeling due to the high degree of uncertainty intrinsic to influenza pandemics (46). Nonetheless, the Panel recommends that organizations consider the use of simulation modeling as one means of becoming better prepared for future pandemics.

A(H1N1) pandemic. Although transnational NGOs and Latin American governments coordinated efforts to provide expert guidance and support before, during, and after the recent $\mathrm{A}(\mathrm{H} 1 \mathrm{~N} 1)$ pandemic $(19,47,48)$, there were no uniform, well-coordinated efforts between government agencies and national NGOs. The Panel recommends improved coordination between government and national NGOs in influenza preparedness efforts, both within and between Latin American countries, and the use of the WHO PIP framework as a useful foundation for the Latin American response.

5. What medical interventions are needed to reduce the adverse impact of influenza in Latin America?

Many simple and low-cost strategies, including isolation, quarantine, social distancing, improved hygiene (e.g., more frequent hand washing and the use of surgical or N95 [95\% filter efficiency] masks, gowns, face shields or goggles, gloves, etc.), and a combinations of all of the above, can interrupt or reduce the spread of influenza viruses (49). At the community level, interventions that incorporate social distancing (e.g., home isolation, school closures, and reduction of workplace contacts) are an important part of PIP plans and can help decrease the viral attack rate. However, these types of interventions are complex and thus require leadership from local health authorities.

At the hospital level, the risk of transmission by direct and indirect contact is well recognized. While recently published data show increased hospital transmission of pandemic $\mathrm{A}(\mathrm{H} 1 \mathrm{~N} 1)$ versus seasonal strains (50), the recommended approach to infection control for both types of viruses is the same: improved hygiene (as described above) among all health care workers providing direct patient care, as well as family members and visitors, and vaccination of everyone who comes into contact with influenza patients. Extended-care facility residents and their caretakers should also be vaccinated (on an annual basis).

Mono- or multivalent influenza immunizations are the most effective medical intervention to date, and their administration is recommended as soon as the correspondent seasonal or pandemic vaccine is available. Although coverage has increased in recent years, influenza vaccines are still underutilized in Latin America. As of December 2008, only 35 out of 43 Latin American countries had incorporated the vaccination into their public health systems, and 33 of those 35 vaccination programs only covered older adults (6).

There is an urgent need for Latin American countries to expand immunization programs (from selective to broad coverage of high-risk groups) as well as vaccine production and distribution (to meet the sharply increasing demand). Current vaccination rates of high-risk groups in Latin America are well below both national and regional goals. Immunization with the standard seasonal or adjuvanted influenza vaccine is recommended region-wide for adults aged 60 to 65 and older (51). The new intradermal vaccine is indicated for adults 18 to 59 years old (31).

Major efforts are under way to produce a Latin American adult influenza immunization schedule flexible enough to be useful for all countries in the region. These include a recent initiative by the Asociación Panamericana de Infectología (API) and PAHO to produce and distribute an updated manual on adult influenza vaccination.

As mentioned above, vaccination of all adults in Latin America is the ultimate goal. When that is not possible, due to limited resources or other factors, countries in the region should, as soon as possible, establish the infrastructure and political plans required to provide cost-effective immunization to, at a minimum, all individuals at high risk of contracting the disease and all individuals that could transmit it to those at high risk (e.g., health care workers).

While antiviral medications can be used for prophylaxis as well as treatment, they should be considered adjuncts to vaccination (not substitutes for it). There are two main groups of anti- virals that exhibit anti-influenza activity: ion channel blockers, such as orally administered amantadine and rimantadine, and neuraminidase inhibitors, such as orally administered oseltamivir and nasally nebulized zanamivir. A recent meta-analysis by Jefferson et al. suggests the use of amantadine and rimantadine be discouraged based on data indicating both drugs are associated with unwanted side effects as well as viral resistance, and the fact that neither drug prevents infection or diminishes viral excretion (even though both have some symptomatic effect on influenza A) (52).

Neuraminidase inhibitors used for pre-exposure prophylaxis may confer some protection against symptomatic influenza but have no significant effect on asymptomatic disease $(53,54)$. As post-exposure prophylaxis, their effectiveness is higher $(52,55)$. When used as treatment, both oseltamivir and zanamivir can reduce the time to symptom alleviation and are effective in preventing complications. Neither drug is associated with significant side effects. Neuraminidase inhibitors should probably be avoided in mild influenza in otherwise healthy patients, and encouraged in serious epidemic or pandemic situations, in conjunction with vaccination and physical interventions (52).

\section{MAIN RECOMMENDATIONS}

1. The Panel urges all health authorities, NGOs, and medical societies to make an effort to enhance surveillance systems and reporting capabilities. Ideally, data collection should be consistent across all countries in the region so that the resulting data can be applied region-wide.

2. The following test sequence should be used for diagnosis: First, a sample should be sent for direct immunofluorescence testing. If the result is negative, either an RT-PCR or rRT-PCR should be performed to confirm the absence of influenza virus. In facilities without access to any PCR methodology, a negative fluorescent antibody test, clinical symptoms, and the presence of many other influenza cases in the population can be considered indicative of influenza. If neither fluorescent antibody nor PCR methods are available, a definitive diagnosis of influenza cannot be confirmed. 
3. There should be much closer involvement between government agencies and NGOs with regard to influenza preparedness both within and between Latin American countries, and the WHO PIP framework should be used as a foundation for the Latin American response.

1. World Health Organization. Influenza Fact Sheet No 211 [Internet]. Geneva: WHO; 2003. Available from: http://www.who.int/media centre/factsheets/2003/fs211/en/ Accessed 20 May 2008.

2. Centers for Disease Control and Prevention (US). Estimates of deaths associated with seasonal influenza-United States, 1976-2007. MMWR Morb Mortal Wkly Rep. 2010;59(33):1057-62.

3. Isturiz RE, Luna CM, Ramirez J. Clinical and economic burden of pneumonia among adults in Latin America. Int J Infect Dis. 2010;14(10):e852-6.

4. Kuri-Morales $\mathrm{P}$, Galván F, Cravioto $\mathrm{P}$, Zárraga Rosas LA, Tapia-Conyer R. Mortalidad en México por influenza y neumonía (1990-2005). Salud Publica Mex. 2006;48(5):379-84

5. World Health Organization. Influenza vaccines. WHO position paper. Wkly Epidemiol Rec. 2005;80(33):279-87. Available from: http://www.who.int/immunization/wer 8033influenza_August2005_position_paper. pdf Accessed 5 January 2012.

6. Ropero-Alvarez AM, Kurtis HJ, DanovaroHolliday MC, Ruiz-Matus C, Andrus JK. Expansion of seasonal influenza vaccination in the Americas. BMC Public Health. 2009;9(1):361.

7. Wenzel RP, Edmond MB. Preparing for 2009 H1N1 influenza. N Engl J Med. 2009;361(20):1991-3.

8. Bridges CB, Kuehnert MJ, Hall CB. Transmission of influenza: implications for control in health care settings. Clin Infect Dis. 2003;37(8):1094-101.

9. Racaniello V. Comments on "Influenza A/ Mexico/2009 (H1N1) virulence and transmission." 2009 May 12. In: Racaniello V. Virology blog: about viruses and viral disease [Internet]. New York: Vincent Racaniello; c20042012. Available from: http://www.virology. ws/2009/05/12/influenza-h1n1-virulencetransmission Accessed 15 September 2010.

10. Libster R, Bugna J, Coviello S, Hijano DR, Dunaiewsky M, Reynoso N, et al. Pediatric hospitalizations associated with 2009 pandemic influenza A (H1N1) in Argentina. N Engl J Med. 2010;362(1):45-55.

11. Moura FE. Influenza in the tropics. Curr Opin Infect Dis. 2010;23(5):415-20.

12. Alonso WJ, Viboud C, Simonsen L, Hirano EW, Daufenbach LZ, Miller MA. Seasonality of influenza in Brazil: a traveling wave from the Amazon to the subtropics. Am J Epidemiol. 2007;165(12):1434-42.

13. Finkelman BS, Viboud C, Koelle K, Ferrari MJ, Bharti N, Grenfell BT. Global patterns in
4. The Panel recommends a long-term goal of universal adult vaccination region-wide, and a short-term goal of vaccination of all populations at high risk of acquiring the virus or disseminating it to others, as well as those especially vulnerable to influenza complications.

\section{REFERENCES}

seasonal activity of influenza A/H3N2, A/ H1N1, and B from 1997 to 2005: viral coexistence and latitudinal gradients. PLoS One. 2007;2(12):e1296.

14. Ramírez AP, Mendoza AR, Montoya JM, Cótes K, López JD, Herrera D, et al. Mortalidad asociada con las temporadas de mayor circulación de los virus de la influenza en Bogotá, Colombia, 1997-2005. Rev Panam Salud Publica. 2009;26(5):435-9.

15. Echavarría M, Querci M, Marcone D, Videla C, Martínez A, Bonvehi P, et al. Pandemic (H1N1) 2009 cases, Buenos Aires, Argentina. Emerg Infect Dis. 2010;16(2):311-3.

16. Richard SA, Viboud C, Miller MA. Evaluation of Southern Hemisphere influenza vaccine recommendations. Vaccine. 2010;28(15):2693-9.

17. Wang R, Taubenberger JK. Methods for molecular surveillance of influenza. Expert Rev Anti Infect Ther. 2010;8(5):517-27.

18. Nguyen JT, Hoopes JD, Smee DF, Prichard MN, Driebe EM, Engelthaler DM, et al. Triple combination of oseltamivir, amantadine, and ribavirin displays synergistic activity against multiple influenza virus strains in vitro. Antimicrob Agents Chemother. 2009;53(10): 4115-26.

19. Mensua A, Mounier-Jack S, Coker R. Pandemic influenza preparedness in Latin America: analysis of national strategic plans. Health Policy Plan. 2009;24(4):253-60. Available from: http://heapol.oxfordjournals.org/ content/24/4/253 Accessed 5 January 2012.

20. Harper SA, Bradley JS, Englund JA, File TM, Gravenstein S, Hayden FG, et al. Seasonal influenza in adults and children-diagnosis, treatment, chemoprophylaxis, and institutional outbreak management: clinical practice guidelines of the Infectious Diseases Society of America. Clin Infect Dis. 2009;48(8): 1003-32.

21. Cox NJ, Subbarao K. Influenza. Lancet. 1999;354(9186):1277-82.

22. Gross PA, Russo C, Dran S, Cataruozolo P, Munk G, Lancey SC. Time to earliest peak serum antibody response to influenza vaccine in the elderly. Clin Diagn Lab Immunol. 1997;4(4):491-2

23. Cate TR, Couch RB, Parker D, Baxter B. Reactogenicity, immunogenicity, and antibody persistence in adults given inactivated influenza virus vaccines-1978. Rev Infect Dis. 1983;5(4):737-47.

24. Lerman SJ, Wright PF, Patil KD. Antibody decline in children following A/New Jersey/ 76 influenza virus immunization. J Pediatr. 1980;96(2):271-4.

25. de Mello WA, de Paiva TM, Ishida MA, Benega MA, Dos Santos MC, Viboud C, et
Acknowledgments. The authors thank the Pan American Health and Education Foundation and its staff and advisors, Genevieve Hernandez, Richard Kahn, Stephanie Salvador, and Richard Salvatierra, for their assistance in developing the conference and facilitating the consensus process.

al. The dilemma of influenza vaccine recommendations when applied to the tropics: the Brazilian case examined under alternative scenarios. PLoS One. 2009;4(4):e5095.

26. Reisinger KS, Block SL, Izu A, Groth N, Holmes SJ. Subunit influenza vaccines produced from cell culture or in embryonated chicken eggs: comparison of safety, reactogenicity, and immunogenicity. J Infect Dis. 2009;200(6):849-57.

27. Pellegrini M, Nicolay U, Lindert K, Groth N, Della Cioppa G. MF59-adjuvanted versus non-adjuvanted influenza vaccines: integrated analysis from a large safety database. Vaccine. 2009;27(49):6959-65.

28. Schultze V, D'Agosto V, Wack A, Novicki D, Zorn J, Hennig R. Safety of MF59 adjuvant. Vaccine. 2008;26(26):3209-22.

29. European Medicines Agency. Pandemrix: influenza vaccine $(\mathrm{H} 1 \mathrm{~N} 1)_{\mathrm{V}}$ (split virion, inactivated, adjuvanted) A/California/7/2009 $(\mathrm{H} 1 \mathrm{N1}) \mathrm{v}$ like strain (x-179a) [Internet]. London: EMA; 2009 [updated 25 Nov 2011]. Available from: http://www.ema. europa.eu/ema/index.jsp?curl=pages / medi cines / human/medicines / 000832/ human med_000965.jsp\&mid=WC0b01ac058001d124 Accessed 25 November 2012.

30. Lambert PH, Laurent PE. Intradermal vaccine delivery: will new delivery systems transform vaccine administration? Vaccine. 2008;26(26):3197-208.

31. Van Damme P, Arnou R, Kafeja F, Fiquet A, Richard P, Thomas S, et al. Evaluation of noninferiority of intradermal versus adjuvanted seasonal influenza vaccine using two serological techniques: a randomised comparative study. BMC Infect Dis. 2010;10(1):134.

32. Gurfikel EP, de la Fuente RL. Two-year follow-up of the FLU Vaccination Acute Coronary Syndromes (FLUVACS) Registry. Tex Heart Inst J. 2004;31(1):28-32.

33. Stamboulian D, Bonvehí PE, Nacinovich FM, Rüttimann RW. Immunization against influenza in the elderly: the Argentinian experience, 1993-1997. Vaccine. 1999;17 Suppl 1:S53-6.

34. Mannino S, Villa M, Weiss N, Apolone G, Rothman KJ. Effectiveness of influenza vaccination with Fluad versus a sub-unit influenza vaccine. Abstracts of the 43rd Annual Meeting of the Society for Epidemiologic Research, 23-26 June, Anaheim, California. Am J Epidemiol. 2010;171(Suppl 11):S157.

35. Steinhoff MC, Omer SB, Roy E, Arifeen SE Raqib R, Altaye M, et al. Influenza immunization in pregnancy-antibody responses in mothers and infants. New Engl J Med. 2010;362(17):1644-6. 
36. Zaman K, Roy E, Arifeen SE, Rahman M, Raqib $\mathrm{R}$, Wilson E, et al. Effectiveness of maternal influenza immunization in mothers and infants. New Engl J Med. 2008;359(15):1555-64. Erratum in: New Engl J Med. 2009;360(6):648. Breiman, Robert E [corrected to Breiman, Robert F].

37. Loeb M, Russell ML, Moss L, Fonseca K, Fox J, Earn DJ, et al. Effect of influenza vaccination of children on infection rates in Hutterite communities: a randomized trial. JAMA. 2010;303(10):943-50.

38. Glezen WP, Gaglani MJ, Kozinetz CA, Piedra PA. Direct and indirect effectiveness of influenza vaccination delivered to children at school preceding an epidemic caused by 3 new influenza virus variants. J Infect Dis. 2010;202(11):1626-33.

39. Lewin EB. A paradigm for the control of influenza. J Infect Dis. 2010;202(11):1619-22.

40. Reichert TA. The Japanese program of vaccination of schoolchildren against influenza: implications for control of the disease. Semin Pediatr Infect Dis. 2002;13(2):104-11.

41. Sivadon-Tardy V, Orlikowski D, Porcher R, Sharshar T, Durand MC, Enouf V, et al. Guillain-Barré syndrome and influenza virus infection. Clin Infect Dis. 2009;48(1):48-56.

42. de Lataillade C, Auvergne S, Delannoy I. 2005 and 2006 seasonal influenza vaccination coverage rates in 10 countries in Africa, Asia Pacific, Europe, Latin America and the Middle East. J Public Health Policy. 2009;30(1):83-101.

43. Stamboulian D, Bonvehí PE, Nacinovich FM, Cox N. Influenza. Infect Dis Clin North Am. 2000;14(1):141-66.
44. World Health Organization. Pandemic influenza preparedness and response: a WHO guidance document. Geneva: WHO Global Influenza Programme; 2009. Available from: http://whqlibdoc.who.int/publications/2009/ 9789241547680 eng.pdf Accessed 8 November 2010.

45. Halder N, Kelso JK, Milne GJ. Analysis of the effectiveness of interventions used during the 2009 A/H1N1 influenza pandemic. BMC Public Health. 2010;10(1):168.

46. Lipsitch M, Riley S, Cauchemez S, Ghani AC, Ferguson NM. Managing and reducing uncertainty in an emerging influenza pandemic. New Engl J Med. 2009;361(2):112-5.

47. Buss P, Koplan JP, Dusenbury C, Binder S, Rosenberg F. Los institutos nacionales de salud pública: un enfoque coordinado e integral contra la influenza A H1N1 y otras amenazas a la salud pública. Rev Panam Salud Publica. 2009;26(2):184-8.

48. Mujica OJ, Olivia O, dos Santos T, Ehrenberg JP. Planificación de la preparación para la influenza pandémica: esfuerzos regionales. Rev Panam Salud Publica. 2008;23(6);428-34.

49. Jefferson T, Del Mar C, Dooley L, Ferroni E, Al-Ansary LA, Bawazeer GA, et al. Physical interventions to interrupt or reduce the spread of respiratory viruses: systematic review. BMJ. 2009;339:b3675. doi: 10.1136/bmj. b3675.

50. Rabagliati R, Labarca J, Siri L, Perez CM, Ferrés M. Rates of hospital-acquired influenza due to the pandemic H1N1 virus in 2009, compared with seasonal influenza. Infect Control Hosp Epidemiol. 2011;32(2):198-200.
51. Ministerio de Salud (AR). Lineamientos técnicos. Campaña Nacional de Vacunación Antigripal: Argentina 2011. Buenos Aires: MS; 2011. Available from: http://www.msal.gov. ar/gripe2011/5_equipos/info_equipos/lin eamientos tecnicos gripe 2011.pdf Accessed 10 January 2012.

52. Jefferson T, Demicheli V, Rivetti D, Jones M, Di Pietrantonj C, Rivetti A. Antivirals for influenza in healthy adults: systematic review. Lancet. 2006;367(9507):303-13. Erratum in: Lancet. 2006;367(9528):2060.

53. Hayden FG, Atmar RL, Schilling M, Johnson C, Poretz D, Paar D, et al. Use of the selective oral neuraminidase inhibitor oseltamivir to prevent influenza. New Engl J Med. 1999;341(18):1336-43.

54. Monto AS, Robinson DP, Herlocher ML, Hinson JM Jr, Elliot MJ, Crisp A. Zanamivir in the prevention of influenza among healthy adults: a randomized controlled trial. JAMA. 1999;282(1):31-5.

55. Welliver $\mathrm{R}$, Monto AS, Carewicz O, Schatteman E, Hassman M, Hedrick J, et al. Effectiveness of oseltamivir in preventing influenza in household contacts: a randomized controlled trial. JAMA. 2001;285(6):748-54.

Manuscript received on 8 July 2011. Revised version accepted for publication on 8 February 2012.

RESUMEN En América Latina, la gripe en adultos es una enfermedad grave que impone una carga importante en cuanto a la morbilidad, la mortalidad y el costo. Aunque se ha escrito mucho acerca de la enfermedad en sí, se ha recopilado relativamente escasa información sobre lo que podría hacerse para reducir su repercusión en la región, en particular desde la perspectiva de los médicos con experiencia directa en afrontar sus efectos. Para compensar esta falta de información, en 2011 la Fundación Panamericana de la Salud y Educación (PAHEF) y la organización sin fines de lucro establecida en los Estados Unidos Fighting Infectious Diseases in Emerging Countries (FIDEC) organizaron una conferencia y convocaron a un panel de científicos y médicos latinoamericanos con experiencia y conocimientos especializados en la gripe en adultos en la región a fin de 1) analizar los temas principales relacionados con la enfermedad y 2) elaborar y emitir una declaración de consenso que resuma la repercusión, así como los logros actuales en el diagnóstico, la prevención y el tratamiento de la enfermedad. El panel de consenso llegó a la conclusión que se requieren esfuerzos más concertados y mejor coordinados para reducir la repercusión adversa de la gripe estacional y las pandemias futuras, que comprenden una mayor vigilancia, una participación más activa de las organizaciones gubernamentales y no gubernamentales y un esfuerzo mucho mayor para vacunar a más adultos, en especial a las personas que presentan un riesgo elevado de contraer la enfermedad. Además, se recomendó un nuevo enfoque para diagnosticar la gripe.

Palabras clave Gripe humana; inmunización; vacunas contra la influenza; adulto; conferencias de consenso como asunto; América Latina. 